\title{
Multikultural dalam Perspektif Alquran
}

\author{
Heru Suparman \\ Universitas Indraprasta PGRI, Jakarta \\ pahe165@yahoo.co.id
}

DOI: http://dx.doi.org/10.29240/alquds.v1i2.250

Submitted: 2017-10-27| Revised: 2017-11-26| Accepted: 2017-12-01

\begin{abstract}
Multicultural in the Perspective of the Qur'an. Findings of the research suggest that the views or reviews of the Qur'an about multicultural do not against the Islamic teachings at any rate, especially the Qur'an as the source of Islamic law. The diversity that exist has in fact become intellectual property to be studied, as the Qur'an explains it. Through multicultural, it is expected that every individual and/or every group be acceptance and appreciate toward differences among them, live said by said in harmony in order to establish a peaceful and properous nation. This research used qualitative design and the library research approach, While the method used is documentary method.
\end{abstract}

Keywords: multicultural, Alquran, universal wisdom

Abstrak: Temuan penelitian menunjukkan bahwa pandangan atau ulasan Alquran tentang multikultural sama sekali tidak bertentangan dengan ajaran Islam, terutama Alquran sebagai sumber hukum Islam. Keragaman yang ada sebenarnya telah menjadi kekayaan intelektual untuk dipelajari, seperti yang dijelaskan Alquran. Melalui multikultural, diharapkan setiap individu dan/atau setiap kelompok mendapat penerimaan dan menghargai perbedaan di antara mereka, hidup dikatakan dengan kata selaras agar bisa membangun negara yang damai dan layak. Penelitian ini menggunakan desain kualitatif dan pendekatan penelitian perpustakaan, Sedangkan metode yang digunakan adalah metode dokumenter.

Kata kuci: multikultural, alquran, kearifan universal

\section{Pendahuluan}

Indonesia merupakan salah satu negara dengan penduduk yang sangat majemuk. Kenyataan ini dapat dilihat dari dinamika kehidupan masyarakat yang beragam, baik dalam aspek keagamaan, suku bangsa, bahasa maupun budaya. Keragaman yang ada, sesungguhnya dapat menjadi salah satu potensi besar bagi kemajuan bangsa. Namun di lain pihak, juga berpotensi menimbulkan berbagai 
macam permasalahan apabila tidak dikelola dan dibina dengan baik. Umat muslim sebagai pemeluk agama yang mayoritas, harus berperan aktif dalam mengelola dimensi keragaman bangsa ini. Pendidikan Islam sebagai salah satu instrumen penting peradaban umat, perlu dioptimalkan sebaik mungkin untuk menata dinamika keragaman agar dapat menjadi potensi kemajuan. Perbedaanperbedaan yang muncul disekitar kehidupan manusia telah diilustrasikan dalam Surat al-Hujurat/49:13.

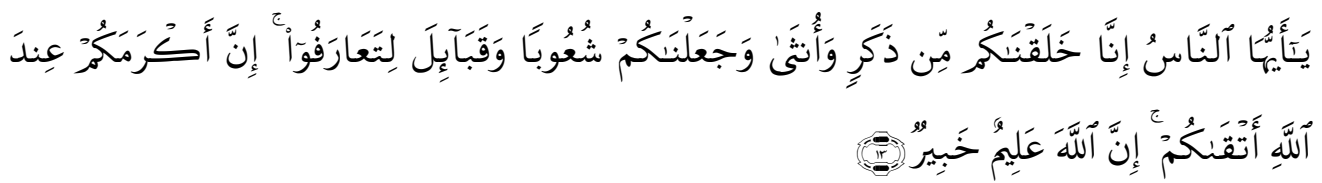

Wahai manusia! Sungguh, Kami telah menciptakan kamu dari seorang laki-laki dan seorang perempuan, kemudian Kami jadikan kamu berbangsa - bangsa dan bersuku-suku agar kamu saling mengenal. Sungguh yang paling mulia diantara kamu disisi Allah ialah orang yang paling bertaqwa. Sungguh Allah Maha mengetahui, Mahateliti.

Ayat ini menurut penuturan para mufasirin secara substansial menegaskan keberagaman umat manusia dari berbagai sisi. Dalam konteks Alquran diturunkan untuk mencerminkan keragaman manusia secara geografis, sementara dalam konteks saat ini mewakili keragaman geo-politik, kultural maupun negara bangsa (nation-state).

Multikultural secara sederhana dapat dipahami sebagai pengakuan bahwa sebuah negara atau masyarakat adalah beragam dan majemuk. Sebaliknya tidak ada satu negara pun yang mengandung hanya kebudayaan nasional tunggal. Dengan demikian, multikulturalisme merupakan sunatullah yang tidak dapat ditolak bagi setiap negara-bangsa di dunia ini. ${ }^{1}$

Kemajemukan dan multikultural mengisyaratkan adanya perbedaan. Bila dikelola secara benar, kemajemukan dan multikultural menghasilkan kekuatan positif bagi pembangunan bangsa. Sebaliknya, bila tidak dikelola secara benar, kemajemukan dan multikultural bisa menjadi faktor destruktif dan menimbulkan bencana dahsyat. Konflik dan kekerasan sosial yang sering terjadi antar kelompok masyarakat merupakan bagian dari kemajemukan dan multikultural yang tidak dikelola dengan baik.

Terlepas pro dan kontra yang ada, multikultural merupakan fakta yang tergelar di hadapan kita, sebab masyarakat Indonesia adalah masyarakat yang heterogen dan multikultur dengan beragam etnis dan budaya. Dalam kondisi demikian, yang dibutuhkan bukanlah monokultural tetapi multikultural, bukan pembauran tetapi pembaruan, bukan ko-eksistensi tetapi pro-eksistensi, bukan sikap eksklusif melainkan sikap inklusif, bukan separasi tetapi interaksi. Bukan

${ }^{1}$ Zakiyuddin Baidhawy, Pendidikan Agama Berwawasan Multikultural. Jakarta: Erlangga, 2005, h. 7. 
juga kemajemukan demi kemajemukan, atau kemajemukan sekedar warnawarni, tetapi kemajemukanyang dibangun di atas landasan multikutlural yang partisipatorik dan emanipatorik.

Konsep multikultural tidaklah dapat disamakan dengan konsep keanekaragaman secara suku bangsa atau kebudayaan suku bangsa yang menjadi ciri masyarakat majemuk saja, karena multikultural menekankan keanekaragaman kebudayaan dalam kesederajatan. Multikultural adalah sebuah ideologi yang mengakui dan mengagungkan perbedaan dalam kesederajatan baik secara individual maupun secara kebudayaan. ${ }^{2}$

Multikultural adalah kearifan untuk melihat keanekaragaman budaya sebagai realitas fundamental dalam kehidupan bermasyarakat. Kearifan ini terwujud apabila seseorang membuka diri untuk menjalani kehidupan bersama dengan melihat realitas plural sebagai sebuah kemestian yang tidak bisa diingkari ataupun ditolak, apalagi dimusnahkan.

Persoalan yang kemudian muncul dalam masyarakat majemuk adalah konflik, yang dengan sendirinya bisa mengguncang tatanan sosial yang telah lama mengakar. Sehingga multikultural sebenarnya merupakan buah perjalanan panjang intelektual manusia setelah berjumpa dan bergelut dengan berbagai konflik. Multikultural adalah posisi intelektual yang menyatakan keberpihakannya pada pemaknaan terhadap persamaan, keadilan, dan kebersamaan untuk memperkecil ruang konflik yang destruksif. ${ }^{3}$

Kesadaran adanya keberagaman budaya disebut sebagai kehidupan multikultural. Akan tetapi tentu, tidak cukup hanya sampai disitu. Bahwa suatu kemestian agar setiap kesadaran akan adanya keberagaman, mesti ditingkatkan lagi menjadi apresiasi dan dielaborasi secara positif. pemahaman ini yang disebut sebagai multikulturalisme.

Sebagai energi positif, multikultur dipahami sebagai rahmat dari Allah yang telah menciptakan manusia dengan phisical and spiritual force berbeda. Keberadaan tersebut dapat dijadikan sebagai pelengkap satu sama lain.

\section{Multikultural dalam Alquran}

Alquran sebagai sumber ajaran Islam diturunkan oleh Allah SWT. kepada umat manusia melalui Nabi Muhammad SAW. untuk menjadi petunjuk agar manusia memperoleh kebahagiaan dan keselamatan di dunia dan di akhirat melalui jalan yang ditunjuki-Nya. Hal ini ditegaskan dalam firman Allah surat alBaqarah/2: 185 sebagai berikut,

2 Parsudi Suparlan, "Meniju Masyarakat Indonesia yang Multikultural," dalam makalah yang diseminarkan pada Simposium Internasional ke-3, Denpasar Bali, 16-21 Juli 2002, h. 1.

${ }^{3}$ Choirul Mahfud, Pendidikan Multikultural, Yogyakarta: Pustaka Pelajar, 2006, h. 32. 


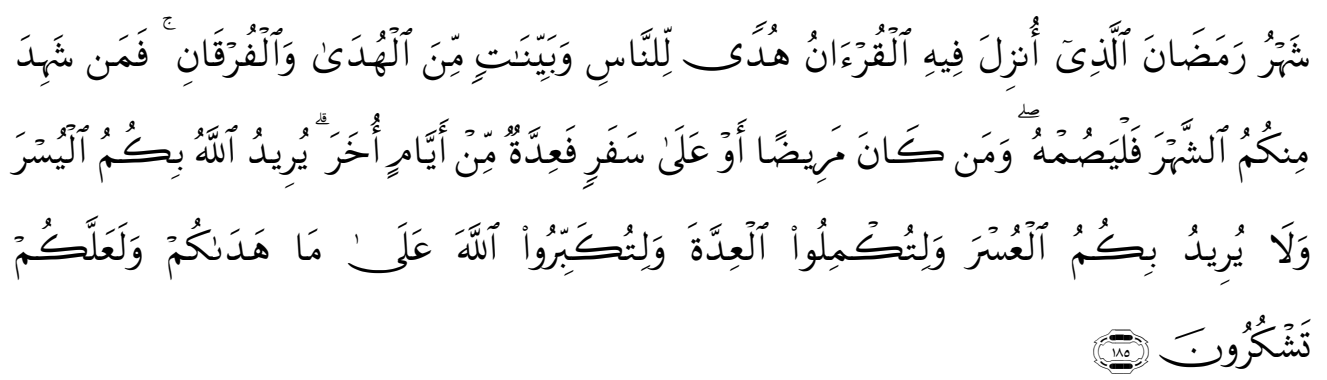

(Beberapa hari yang ditentukan itu ialah) bulan Ramadhan, bulan yang di dalamnya diturunkan (permulaan) Al Quran sebagai petunjuk bagi manusia dan penjelasan-penjelasan mengenai petunjuk itu dan pembeda (antara yang bak dan yang bathil). Karena itu, barangsiapa di antara kamu hadir (di negeri tempat tinggalnya) di bulan itu, maka bendaklah ia berpuasa pada bulan itu, dan barangsiapa sakit atau dalam perjalanan (lalu ia berbuka), maka (wajiblah baginya berpuasa), sebanyak hari yang ditinggalkannya itu, pada hari-hari yang lain. Allah menghendaki kemudahan bagimu, dan tidak menghendaki kesukaran bagimu. Dan hendaklah kamu mencukupkan bilangannya dan hendaklah kamu mengagungkan Allah atas petunjuk-Nya yang diberikan kepadamu, supaya kamu bersyukur.

Dalam firman Allah surat Ibrahim/14: 1 yang berbunyi :

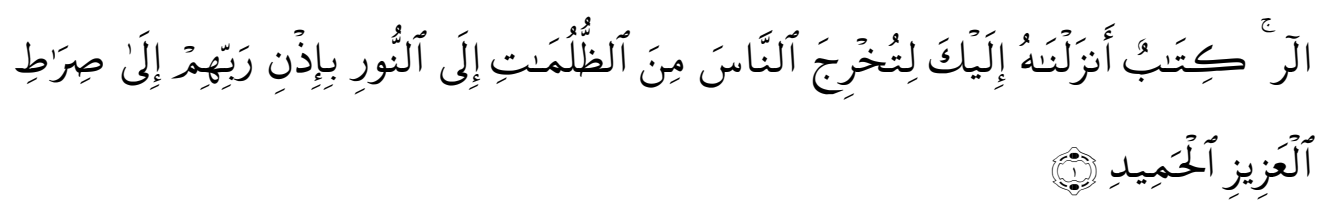

Alif, laam raa. (ini adalah) kitab yang Kami turunkan kepadamu (Mubammad) agar engkau mengeluarkan manusia dari kegelapan kepada cahaya terang benderang dengan izin Tuban, (yaitu) menuju jalan Tuban Yang Maba Perkasa, Maba Terpuji.

Sebagai sebuah kitab petunjuk yang universal Alquran memuat ayat-ayat yang berisi pedoman-pedoman dan pokok-pokok peraturan yang sangat dibutuhkan manusia untuk mengatur kehidupannya, baik yang berhubungan dengan keimanan, maupun peraturan-peraturan yang mengatur tingkah laku dan tata cara hidup manusia baik secara personal maupun komunal. Dari sekian banyak petunjuk yang terdapat di dalam Alquran terdapat ayat-ayat yang berisi pesan-pesan yang seharusnya menjadi pedoman bagi umat manusia terhadap upaya menjaga kerukunan dan kedamaian dalam kehidupan yang multikultural.

Diantara pesan-pesan yang bersifat multikultural tersebut adalah :

Pertama. Alquran menyatakan bahwa manusia diciptakan dari asal yang sama. Sebagaimana dijelaskan di dalam surat al-Hujurat/49: 13 sebagai berikut, 


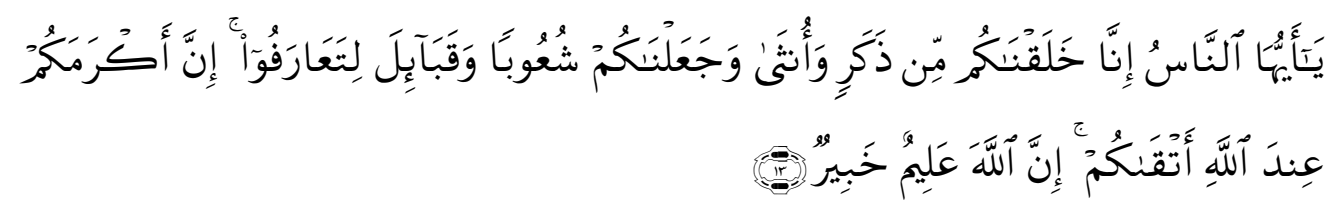

Wahai manusia! Sungguh, Kami telah menciptakan kamu dari seorang laki-laki dan seorang perempuan, kemudian Kami jadikan kamu berbangsa - bangsa dan bersuku-suku agar kamu saling mengenal. Sungguh yang paling mulia diantara kamu disisi Allah ialah orang yang paling bertaqwa. Sungguh Allab Maha mengetabui, Mabateliti.

Ayat ini menjelaskan bahwa Allah menciptakan manusia dari asal yang sama sebagai keturunan Adam dan Hawa yang tercipta dari tanah. Seluruh manusia sama di hadapan Allah, manusia menjadi mulia bukan karena suku, warna kulit ataupun jenis kelamin melainkan karena ketaqwaannya. Kemudian dijadikan berbangsa-bangsa dan bersuku-suku. Tujuan penciptaan semacam itu bukan untuk saling menjatuhkan, menghujat, dan bersombong-sombongan melainkan agar masing-masing saling kenal-mengenal untuk menumbuhkan rasa saling menghormati dan semangat saling tolong-menolong. Dari paparan ayat ini dapat di pahami bahwa agama Islam secara normatif telah menguraikan tentang kesetaraan dalam bermasyarakat yang tidak mendiskriminasikan kelompok lain.

Kedua. Alquran menyatakan bahwa dulu manusia adalah umat yang satu. Saat timbul perselisihan, Allah mengutus para Nabi, sebagai pemberi kabar gembira dan pemberi peringatan. Dan Allah menurunkan bersama mereka kitab yang berisi petunjuk, untuk memberikan keputusan yang benar dan lurus diantara manusia tentang perkara yang mereka perselisihkan. Sebagaimana dijelaskan di dalam Surat Al-Baqarah/2: 213 sebagai berikut,

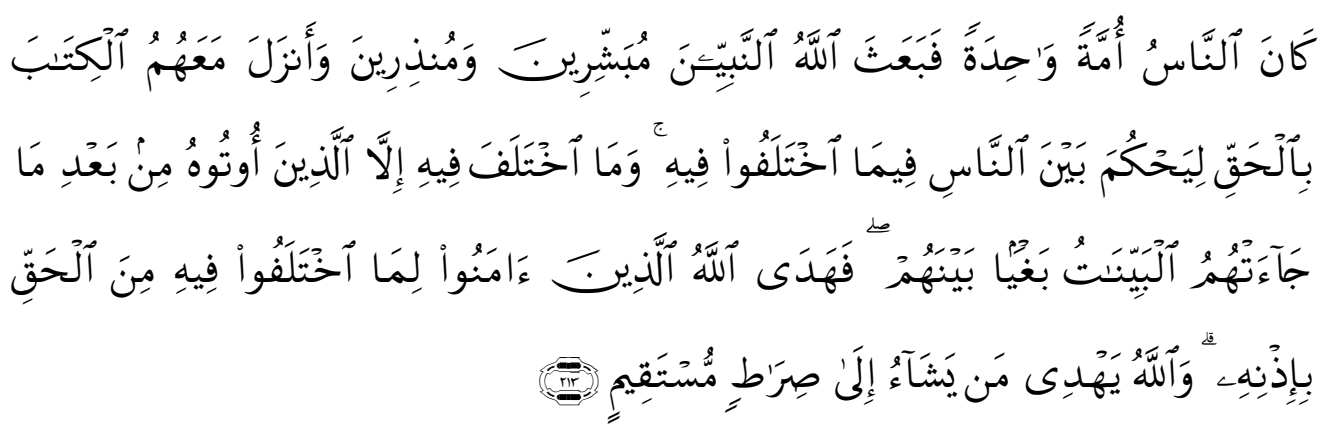

Manusia itu adalah umat yang satu. (setelah timbul perselisihan), Maka Allah mengutus Para Nabi, sebagai pemberi peringatan, dan Allah menurunkan bersama mereka kitab yang benar, untuk memberi keputusan di antara manusia tentang perkara yang mereka perselisibkan. tidaklah berselisih tentang kitab itu melainkan orang yang telah didatangkan kepada mereka Kitab, Yaitu setelah datang kepada mereka keterangan-keterangan yang nyata, karena dengki antara mereka sendiri. Maka Allab memberi petunjuk orang-orang yang beriman kepada kebenaran tentang hal yang mereka perselisibkann itu dengan 
kehendak-Nya. dan Allah selalu memberi petunjuk orang yang dikehendaki-Nya kepada jalan yang lurus.

Dari ayat ini dapat dipahami bahwa sumber perselisihan, permusuhan dan perpecahan di kalangan umat beragama adalah bukan karena ajaran agama yang dianutnya melainkan karena rasa dengki yang membuat mereka mengabaikan ajaran agamanya masing-masing. Seandainya mereka menghilangkan rasa dengkinya dan murni mengamalkan ajaran agamanya, niscaya tidak terjadi perslisihan semacam itu. Karena, tiap-tiap agama mengajarkan pemeluknya untuk menjadi manusia-manusia yang baik dan menghargai orang lain.

Ketiga. Alquran menekankan akan pentingnya saling percaya, pengertian, dan menghargai orang lain, menjauhi buruk sangka dan mencari kesalahan orang lain. Sebagaimana dijelaskan dalam surat al-Hujurat/49: 12 sebagai berikut,
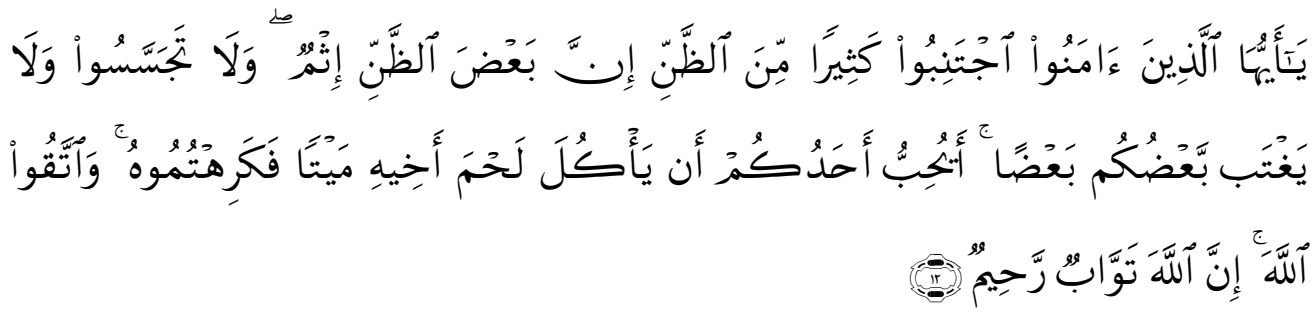

Hai orang-orang yang beriman, jaubilah kebanyakan purba-sangka (kecurigaan), karena sebagian dari purba-sangka itu dosa. dan janganlab mencari-cari keburukan orang dan janganlah menggunjingkan satu sama lain. Adakah seorang diantara kamu yang suka memakan daging saudaranya yang sudah mati? Maka tentulah kamu merasa jïik kepadanya. dan bertakwalah kepada Allah. Sesunggubnya Allah Maha Penerima taubat lagi Maha Penyayang.

Ketika menghadapi permasalahan, Alquran mengajarkan untuk selalu mengedepankan klarifikasi, dialog, diskusi, dan musyawarah. Tidak boleh menjatuhkan vonis tanpa mengetahui dengan jelas permasalahannya. Sebagaimana dijelaskan dalam surat al-Hujurat/49: 6 sebagai berikut,

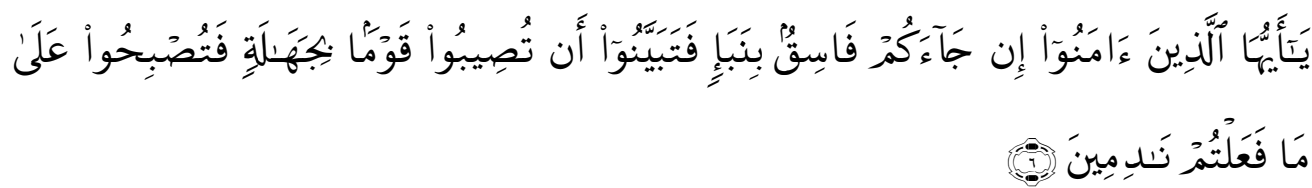

Hai orang-orang beriman, jika datang kepadamu orang Fasik membawa suatu berita, maka periksalah dengan teliti agar kamu tidak menimpakan suatu musibab kepada suatu kaum tanpa mengetabui keadaannya yang menyebabkan kamu menyesal atas perbuatanmu itu. 
Kelima. Alquran menekankan untuk menghindari konflik dan melaksanakan rekonsiliasi atas berbagai persoalan yang terjadi, yakni upaya perdamaian melalui sarana pengampunan atau memaafkan. Pemberian maaf dalam rekonsiliasi adalah tindakan tepat dalam situasi konflik komunal. Dalam ajaran Islam, seluruh umat manusia harus mengedepankan perdamaian, cinta damai dan memberi rasa aman bagi seluruh makhluk. Secara tegas Alquran menganjurkan untuk memberi maaf, membimbing kearah kesepakatan damai dengan cara musyawarah, duduk satu meja dengan prinsip kasih sayang. Hal tersebut terdapat dalam Surat asy-Syuura/42: 40 sebagai berikut,

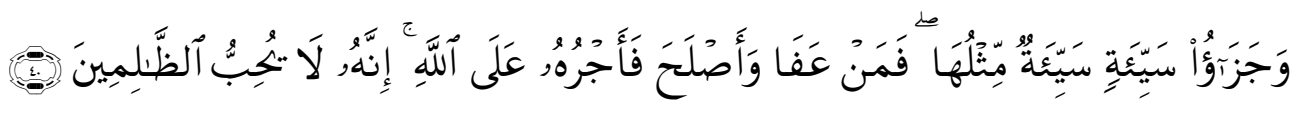

Dan Balasan suatu kejahatan adalah kejahatan yang serupa, Maka barang siapa memaafkan dan berbuat baik, maka pabalanya atas (tanggungan) Allah. Sesunggubnya Dia tidak menyukai orang-orang yang zalim.

Pluralitas sebagai basis multikultural dalam perspektif Islam adalah sunnatullah. Fenomena pluralitas agama dan budaya di kalangan umat manusia dari zaman dahulu kala sampai hari ini adalah fakta yang tidak mungkin diingkari. Pluralitas agama dan budaya dapat juga diungkapkan dalam formula pluralisme agama dan budaya. Sementara itu, Alquran adalah kitab suci yang sejak dini membeberkan pluralitas ini berdasarkan kasat mata, karena hal itu merupakan bagian yang sudah terintegrasi dalam hakikat ciptaan Allah. ${ }^{4}$

Eksistensi manusia yang multikultur menjadi sebuah khazanah ilmu pengetahuan bagi umat Islam untuk dikaji lebih mendalam dan komprehensif. Perbedaan-perbedaan yang muncul di sekitar kehidupan manusia telah diilustrasikan dalam Alquran dan sebagaian orang belum sepenuhnya memahami bahwa multikultural sebagai suatu yang given sebagai takdir Allah.

Lebih lanjut, realitas multikultural juga diintrodusir dalam sejumlah hadist Nabi Muhammad SAW, di antaranya khutbah yang disampaikan oleh Nabi Muhammad SAW. pada hari-hari tasyriq:

'Wahai manusia, camkanlah (oleh kalian): Sesunggubnya Tuban kalian satu dan moyang kalian juga satu. Camkanlah (oleh kalian): Tidak ada keutamaan bagi orang Arab atas non-Arab, begitu juga non-Arab atas Arab, tidak, pula orang kulit merah atas orang hitam maupun orang bitam atas orang berkulit merah kecuali karena (factor) ketakwaan. Sudabkah aku sampaikan?!" (HR. Ahmad). ${ }^{5}$

\footnotetext{
${ }^{4}$ Ahmad Syafi'i Ma'arif, Islam Bingkai Keindonesiaan dan Kemanusiaan: Sebuab Refleksi Sejarah, Bandung: Mizan, 2009, h. 166.

${ }^{5}$ Ahmad ibn Hanbal asy-Syaibani, Musnad al-Imam Abmad ibn Hanbal, Kairo: Mu'assasah Qurtubah, tt., V/411, hadis no. 23536.
} 
Menyikapi keragaman ini, Alquran memberikan rambu- rambu kehidupan, diantaranya dengan tidak memaksakan kehendak orang lain pada aspek tertentu. Allah SWT. Berfirman dalam surat ar-Rum/30: 22 sebagai berikut,

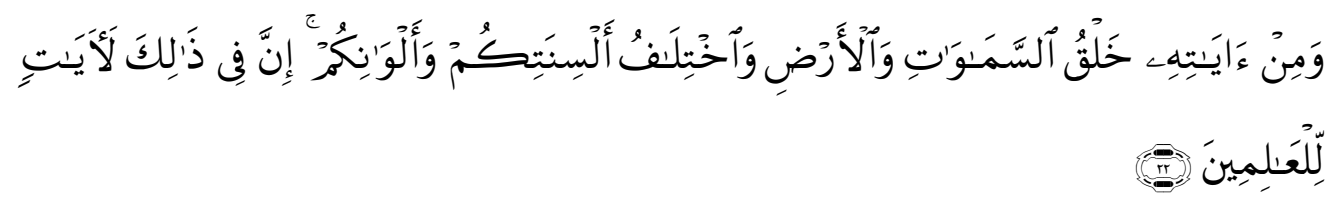

Dan diantara tanda-tanda kekuasaan-Nya ialah menciptakan langit dan bumi dan berlain-lainan bahasamu dan warna kulitmu. Sesunggubnya pada yang demikian itu benar-benar terdapat tanda-tanda bagi orang-orang yang mengetabui.

Muhammad Quraish Shihab dalam Tafsir Al-Misbab menjelaskan: "Alquran demikian menghargai bahasa dan keragamannya, bahkan mengakui penggunaan bahasa lisan yang beragam. Perlu ditegaskan bahwa dalam konteks pembicaraan tentang paham kebangsaan, Alquran sangat menghargai bahasa. Bahasa pikiran dan bahasa perasaan jauh lebih penting ketimbang bahasa lisan, sekalipun bukan berarti mengabaikan bahasa lisan, karena sekali lagi ditekankan bahwa bahasa lisan adalah jembatan perasaan. Atas dasar semua itu, terlihat bahwa bahasa saat dijadikan sebagai perekat dan kesatuan umat, dapat diakui oleh Alquran, bahkan inklusif dalam ajarannya. Bahasanya dan keragamannya merupakan salah satu bukti ke-Esaan dan kebesaran Allah. ${ }^{6}$

Alquran mengingatkan dengan tegas dalam ayat di atas sebagai antisipasi kemungkinan timbulnya sikap dan budaya saling mencemooh dan merendahkan antara kelompok yang satu dengan yang lain. Karena tindakan mencemooh dan mengejek, serta merendahkan orang, apalagi kelompok lain, merupakan cikal dan sumber konflik sosial. ${ }^{7}$

Dalam hal ini ada 2 perspektif untuk mencermati kaitan antara Islam dan multikultural, yaitu normatif dan historis.

Perspektif pertama, dapat ditela'ah dari beberapa ayat Alquran yang berbicara landasan normatif tentang multikultural, di antaranya dalam surat Hud/11: 118 sebagai berikut,

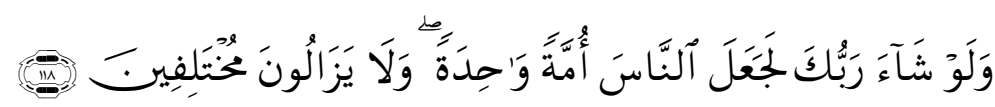

${ }^{6}$ Muhammad Quraish Shihab, Tafsir Al-Misbah, Pesan dan Keserasian Al-Quran Vol.1, Jakarta: Lentera Hati, 2002, h.. 340-342.

7 M. Amin Abdullah, Dinamika Islam Kultural; Pemetaan Wacana Keislaman Kontemporer, Cet. Ke-1, Bandung: Mizan, 2000, h. 77. 
"Iikalau Tuhan mu menghendaki, tentu Dia menjadikan manusia umat yang satu, tetapi mereka senantiasa berselisih pendapat".

Frase "jikalau Tuhanmu menghendaki" ini dipahami oleh mayoritas ahli tafsir sebagai bentuk pengandaian yang tidak memerlukan jawaban (gaya bahasa retoris). Artinya frase ini tidak memerlukan penegasan lebih lanjut. Oleh karena itu, teks dalam surat Hut ini meniscayakan keragaman (multikultural) bagi umat manusia secara umum, bahkan dalam perspektif asy-Syaukani, azZamakhsyari dan al-Alusi, keragaman yang dimaksud adalah keragaman jalan hidup dan agama.

Perspektif kedua, dapat dicermati dari sejarah panjang Rasulullah SAW., yang begitu intens membangun Islam dan multikultural di tengah komunitas yang multietnis, ras, budaya dan agama selama 13 tahun di Makkah kemudian hijrah ke Yasrib yang kemudian berganti nama menjadi Madinah. Situasi saat itu masyarakat yang cukup plural dan multikultural tersebut telah memunculkan inspirasi Rasulullah SAW. Untuk mendirikan apa yang kemudian dikenal dengan "Negara Madinah" tertuang dalam "Piagam Madinah" yang mengandung nilai-nilai universal: keadilan, kebebasan, persamaan hak dan kewajiban serta perlakuan sama di mata hukum.

Walaupun dalam perjalanan dakwahnya sering terjadi benturan dengan masyarakat Jahiliyah. Namun secara substansial, benturan dan peperangan itu hanya ditempuh sebagai alternatif terakhir setelah segala jalan damai yang dimpuh mengalami kegagalan. Dengan demikian, dapat dicermati bahwa sebenarnya Islam tidak pernah mengajarkan umatnya untuk memusuhi, suku, bangsa, budaya dan agama lain. Bahkan sebaliknya, bahwa Islam memerintahkan manusia untuk menjalin kerjasama dan kontak yang baik terhadap siapapun untuk membangun peradaban manusia yang lebih baik.

\section{Multikultural dan Kearifan Universal}

Multikultural adalah kearifan untuk melihat keanekaragaman budaya sebagai realitas fundamental dalam kehidupan bermasyarakat. Kearifan itu segera muncul, jika seseorang membuka diri untuk menjalani kehidupan bersama dengan melihat realitas plural sebagai kemestian hidup yang kodrati, baik dalam kehidupan dirinya sendiri yang multidimensional maupun dalam kehidupan bermasyarakat yang lebih kompleks, dan karenanya muncul kesadaran bahwa keanekaragaman dalam realitas dinamika kehidupan adalah suatu keniscayaan yang tidak bisa ditolak, diingkari, apalagi dimusnahkan.

Multikultural sesungguhnya tidaklah datang secara tiba tiba.Sebagai satu kearifan, multikultural sesungguhnya merupakan buah dari perjalanan intelektual yang panjang, setelah sekian lama bergulat dan terlibat dalam berbagai gejolak dan konflik.Karena itu, multikultural bukan barang dagangan untuk memperjual 
belikan kepada funding seperti yang dituduhkan oleh sejumlah kalangan yang mencurigainya.Multikultural adalah posisi intelektual yang menyatakan keberpihakannya pada pemaknaan terhadap persamaan, keadilan, dan kebersamaan, untuk memperkecil ruang konflik yang destruktif.

Kecurigaan terhadap multikulturalisme di tengah masyarakat konflik, ketidakadilan dan tajamnya kesenjangan dalam berbagai aspek kehidupan masyarakat, sosial, ekonomi, politik, budaya, hukum dan keagamaan seperti sekarang ini memang bisa dimengerti. Dalam setiap konflik sosial, apalagi yang berkembang manjadi kekerasan terbuka, akan muncul sikap-sikap yang hitamputih, kita dan mereka, atau minna wa minhum. Pada tahap ini, multikulturalisme akan dipandang oleh mereka yang terlibat dalam konflik sebagai sikap oportunistik, egoistik, tidak ada kepedulian, dan pertanda dari lemahnya kepercayaan pada Tuhan (iman).

Karena itu, multikultural harus diletakkan pada posisinya yang tepat, apalagi ketika menghadapi konflik yang berbasis pada ras, suku dan keagamaan. Multikultural seharusnya bukan ditempatkan pada posisi untuk keberpihakan negatif yang akan memperparah konflik sehingga makin meluas dan tak terkendali, tetapi pada keberpihakan positif untuk mencari solusi. Solusi tidak mungkin akan dicapai, jika pandangan multikultural tidak dijiwai dengan baik.

Multikultural diibaratkan seperti perjalanan mendaki puncak gunung untuk mendapatkan cakrawala pandangan yang amat luas sehingga tidak terpenjara dalam pandangan yang sempit. Bisa juga dikatakan sebagai perjalanan spiritual dan iman untuk menyatu dengan kesemestaan Ilahi dan melihat anugerah-Nya yang sangat luas dan beranekaragam yang kompleks dalam kehidupan yang dinamis, dan kemudian membuahkan suatu kesalehan sosial yang aktual membangun harmoni kehidupan bersama-sama menghentikan kekerasan, penindasan dan fanatisme sempit.

Pada tahapan ini multikultural sesungguhnya merupakan proses pengkayaan spiritual dan menjadi penjelmaan iman yang cerdas. Iman bukan kata benda, tetapi kata kerja, kreativitas dan moralitas. Iman pada hakikatnya merupakan proses penghayatan dan penjiwaan yang cerdas atas keanekaragaman yang tergenggam dalam sunatullah yang perkasa, sebagai penampakan kebesaran Ilahi, sehingga iman tidak berada dalam ruang yang seragam, statis dan kosong, tetapi dalam keterlibatan yang kreatif dalam dinamika keanekaragaman, perubahan dan konflik, untuk menerangi jalan menuju ke masa depan kehidupan bersama yang lebih damai, sejahtera dan berkeadilan.

Oleh karena itu, multikultural bukanlah sekedar wacana tetapi realitas dinamika, bukan kata-kata, tetapi tindakan, bukan simbol kegenitan intelektual, tetapi keberpihakan yang cerdas untuk mencari solusi yang mencerahkan. 


\section{Multikultural pada Masa Rasulullah SAW}

\section{Multikultural di Madinah}

Membaca sejarah Madinah, khususnya pada masa awal perkembangan Islam seringkali membuat kita terheran dan teragum-kagum. Madinah, sebuah kota yang warganya begitu heterogen, terdiri dari berbagai kultur dan agama, ternyata dapat hidup berdampingan. Hal ini tentu saja tidak bisa dilepaskan dari kerja keras dan kecerdasan Rasulullah Saw yang tentunya juga mendapatkan bimbingan dari Allah Swt.

Masyarakat Madinah adalah potret kehidupan masyarakat modern yang diidealkan oleh banyak orang. Bahkan gambaran tentang masyarakat Madinah seakan menjadi gambaran masyarakat modern yang sudah mapan dan permanen, sehinggat idak sedikit komunitas masayarakat yang menginginkan mangulang kembali sejarah Madinah dalam konteks kehidupan sekarang ini. ${ }^{8}$

\section{a. Keunikan dan Keistimewaan Masyarakat Madinah}

Nurcholis Majid, sebagaimana dikutip Nurul Mubin, ${ }^{9}$ mendefinisakan Madinah dari kata "madinat" yang akar katanya sama dengan kata "madaniyat dan tamaddun" yang artinya adalah peradaban (civilization). Dari aspek kebahasaan kata "madaniyat" adalah hadarat yang menunjukkan pengertian pola hidup menetap di suatu tempat. Dengan demikian Masyarakat Madinah adalah masyarakat yang menetap dalam suatu wilayah tertentu dan menciptakan peradaban.

Madinah adalah kota yang unik dan memiliki banyak keistimewaan. Madinah laksana sebuah putaran roda yang tidak berhenti dari zaman sebelum masehi hingga sekarang ini. Di tengah jatuh bangunnya sebuah peradaban, tetapi madinah sudah terbukti mampu bertahan dari masa ke masa layaknya Mekkah, Madinah telah dititahkan Tuhan menjadi salah satu kota suci-Nya. ${ }^{10}$ Sebagai sebuah pendulum sejarah, Madinah Pra-Islam melewati sejumlah fase sejarah yang unik dan menarik untuk dicermati, yaitu fase Yatsrib, Arab Amalekit, kaum Yahudi, dan suku Arab dari Yaman. Dalam setiap fase mempunya kekhasan tersendiri, yang merupakan karakter dari setiap kelompok. ${ }^{11}$

Awal mula kedatangan orang-orang di madinah ini berasal dari sebuah tragedi yang menimpa kaum Nabi Nuh A.S. Sebagaian dari umatnya tenggelam

${ }^{8}$ Nurul Mubin, Masyarakat Madinah (Islam dan Pembentukan Masyarakat Madani), dalam Tafsir Tematik. Al-Qur'an dan Politik, Center of Exelence for Qur'anic Studies Development, 2008, h.77.

9 Nurul Mubin, Masyarakat Madinab (Islam dan Pembentukan Masyarakat Madani), dalam Tafsir Tematik Al-Qur'an dan Politik,... h.75-76.

10 Zuhairi Misrawi, Madinab: Kota Suci, Piagam Madinah, dan Teladan Muhammad SAW, Penerbit Kompas, 2009, h. 155.

${ }^{11}$ Zuhairi Misrawi, Madinab: Kota Suci, Piagam Madinah, dan Teladan Mubammad SAW,... h. 157 . 
terbawa banjir besar, sedangkan mereka yang mengikuti Nabi Nuh selamat. Setelah berada di atas kapal 1 tahun 10 hari banjir surut dan sebagian dari mereka melancong ke sebuah tempat, yaitu Yatsrib bin Qaniyah bin Mahlail bin Iram bin 'Abil bin 'iWardh bin Iram bin Sam bin Nuh A.S. Mereka datang ke tempat ini pada tahun 2600 SM. Lalu tempat ini dikenal dengan nama Yatsrib sesuai dengan nama orang yang pertama kali datang ke tempat ini. ${ }^{12}$ Kota Yatsrib kemudian diganti Nama oleh Nabi Muahammad Saw menjadi Madinah al-Munawarah. Karena kata yatsrib berarti kerusakan, atau dari dosa. ${ }^{13}$

Keistimewaan Madinah bukan terjadi begitu saja, akan tetapi melalui proses transformasi sosial yang tidak sederhana. Setelah mengganti nama Yastrib dengan Madinah, Nabi kemudian melakukan pemetaan dan sensus penduduk. Barangkali ini merupakan sensus penduduk pertama di dunia. Dalam sensus tersebut ditemukan kenyataan bahwa Madinah adalah sebuah kota yang Multikultural. Heterogenitas kultural masyarakat kota Madinah dapat dilihat dari hasil cacah penduduk yang dilakukan atas perintah Nabi, di mana dari 10.000 jiwa penduduk Madinah kala itu kaum muslim adalah minoritas yakni 1500 orang $(15 \%)$. Mayoritas adalah orang musyrik Arab 4500 orang $(45 \%)$ dan orang Yahudi 4000 orang $(40 \%) .{ }^{14}$ Tingkat heterogenitas ini lebih tinggi lagi manakala dipaparkan bahwa masing-masing kelompok Muslim, Musyrik Arab, dan Yahudi itu di dalamnya terdiri dari berbagai kabilah atau sub-kelompok. Kaum muslim terdiri dari dua kelompok besar Muhajirin (migran) dan Anshor (non-migran), yang masing-masing terdiri dari berbagai suku atau kabilah yang punya tradisi bermusuhan karena kuatnya akar sukuisme dalam masyarakat Arab. Meski begitu, uniknya, kehidupan di Madinah dapat berlangsung dengan damai. Tidak mengherankan jika Madinah menjadi kota yang maju pada masa itu.

\section{b. Potret Multikulturalisme di Madinah}

Multikulturalisme adalah realitas yang sudah ada dalam sejarah umat manusia. Dalam konteks sejarah masyarakat Arab pra Islam, multikulturalisme yang dibingkai dalam keragaman sistem teologi, keragaman suku, budaya dan bahasa adalah wujud nyata dari multikulturalisme tersebut. Karena, multikulturalisme menjadi bagian dari realitas sosial masyarakat saat itu. Ini berarti, multikulturalisme merupakan bagian tak terpisahkan dari realitas sosial

${ }_{12}$ Zuhairi Misrawi, Madinab: Kota Suci, Piagam Madinah, dan Teladan Mubammad SAW,... h. 157.

13 Sami Bin Abdullah al-Maghluts, Al-Ayhlas At-Taikhi Li Sirah ar-Rasul, Atlas Perjalanan Hidup Muhammad, Al-Mahira, Jakarta Cet. 1, 2008, h. 55.

${ }^{14}$ Nurul Mubin, Masyarakat Madinab (Islam dan Pembentukan Masyarakat Madani), dalam Tafsir Tematik. Al-Qur'an dan Politik,... h. 95. 
kehidupan manusia. Dari masa yang sangat dini, multikulturalisme telah ada dan selalu mendampingi sejarah sosial mereka. ${ }^{15}$

Wacana multikulturalisme inilah yang disebut sebagai nilai universal yang memungkinkan antar agama dan keyakinan untuk berbicara segala sesuatu dalam bingkai universalitas, bukan sesuatu yang partikular dan eksklusif. Wacana multikulturalisme sebenarnya tidak berpretensi menghilangkan nilai-nilai partikular dari agama karena upaya seperti itu merupakan hal yang imposible. ${ }^{16}$

Nabi Muhammad saw adalah tokoh yang patut dijadikan teladan dalam hal membumikan multikulturalisme. Ketika Nabi Saw hijrah ke Madinah, beliau mulai memimpin berbagai komunitas yang berbeda latar belakang agama, suku, politik yang disatukan dalam satu bingkai dimana imam sebagai payung hukum utama di atas tata sosial berdasarkan suku dan kabilah tertentu. ${ }^{17}$

Muhammad Saw adalah orang yang berhasil menjadi pemimpin seluruh komponen masyarakat, dan bukan hanya kaum Islam saja. Ketika di Madinah, berbagai budaya, agama dan aliran politik bisa beliau satukan sehingga kehidupan Madinah pada waktu itu dapat berlangsung damai. Muhammad Saw memimpi kominitas besar Yahudi yang banyak menguasai aspek Ekonomi, politik dan kultur di Madinah. Tak hanya itu, ditengah umat kristiani, Muhammad juga terbukti sukses menjadi pemimpin mereka yang kemudian disebut dalam Alquran sebagai Ahlul Kitab. ${ }^{18}$

Belajar dari apa yang dicontohkan Nabi Muhammad SAW dan para sahabatnya yang di Madinah, salah satu persiapan untuk memasuki masyarakat global yang multikultural itu adalah kemampuan managerial untuk mempersatukan kaum muslim yang tidak homogen. Kaum Muslim yang terbelah-belah sudah merupakan realitas sejarah, persoalannya adalah kepemimpinan siapa yang mampu mempersatukan untuk membawa mereka dengan percaya diri dan bermartabat ke kompleksitas masyarakat yang multikultural, bukan hanya sebagai onyek tetapi sebagai inisiator yang mampu mengaktualisasikan ajaran-ajaran Islam sebagai rahmat bagi semua kelompok masyarakat yang ada.

${ }^{15}$ Nurul Mubin, Teologi Multikultural: Upaya Membumikan Dimensi Transendental Di tengah Keragaman Suku, Budaya dan Agama, Jurnal Manarul Qur'an, Nomor: 09 tahun VII, JanuaraiMaret 2001, h. 94.

${ }^{16}$ Nurul Mubin, Teologi Multikultural: Upaya Membumikan Dimensi Transendental Di tengah Keragaman Suku, Budaya dan Agama, ..., h. 95.

${ }^{17}$ Nurul Mubin, Masyarakat Madinah (Islam dan Pembentukan Masyarakat Madani), dalam Tafsir Tematik. Al-Qur'an dan Politik,... h. 97.

${ }^{18}$ Nurul Mubin, Masyarakat Madinah (Islam dan Pembentukan Masyarakat Madani), dalam Tafsir Tematik. Al-Qur'an dan Politik,... h. 98. 
198 | AL QUDS : Jurnal Studi Al Quran dan Hadis vol. 1, no 2, 2017

\section{c. Piagam Madinah dan Ajaran Multikultural}

Menurut Ibnu Hisyam dalam kitab syarahnya Sirah Nabawiyah, piagam Madinah merupakan suatu konstitusi yang dibuat oleh Rasulullah dalam membangun peradaban kota Madinah, menurut Imam Ali ra kesahihan piagam madinah berada setelah Alquran, yang terdiri dari 47 pasal yang menjelaskan tentang tatanan masyarakat sosial Madinah. berikut:

Adapun Prinsip-prinsip dalam piagam madinah ini adalah sebagai

Pertama, Prinsip persatuan dan persaudaraan antar keberagaman suku serta berlaku adil satu sama lain, yang termaktub dalam piagam tersebut pada pasal 1-10. Prinsip ini sesuai dengan firman Allah surat al-Nahl/16: 90 sebagai berikut,

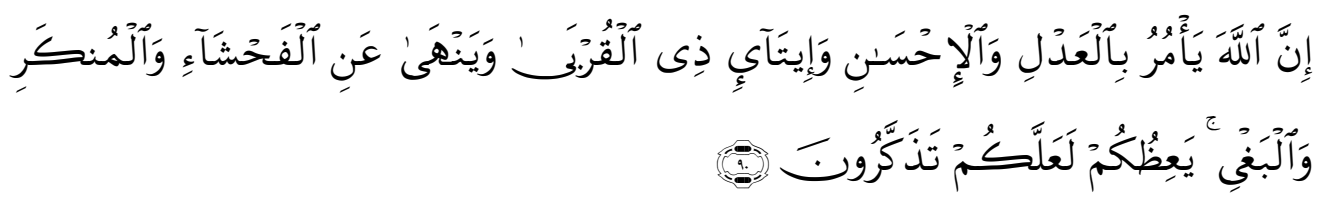

"Sesunggubnya Allah menyuruh (kamu) Berlaku adil dan berbuat kebajikan, memberi kepada kaum kerabat, dan Allah melarang dari perbuatan keji, kemungkaran dan permusuban. Dia memberi pengajaran kepadamu agar kamu dapat mengambil pelajaran"

Kedua, prinsip kebebasan beragama, penetapan prinsip ini merupakan jawaban terhadap situasi sosial penduduk Madinah yang memiliki keragaman komunitas agama dan keyakinan di kota itu. Prinsip ini sesuai dengan pasal ke 25 dalam piagam Madinah, serta bersesuaian dengan firman Allah, surat alBaqarah/2: 256 sebagai berikut,

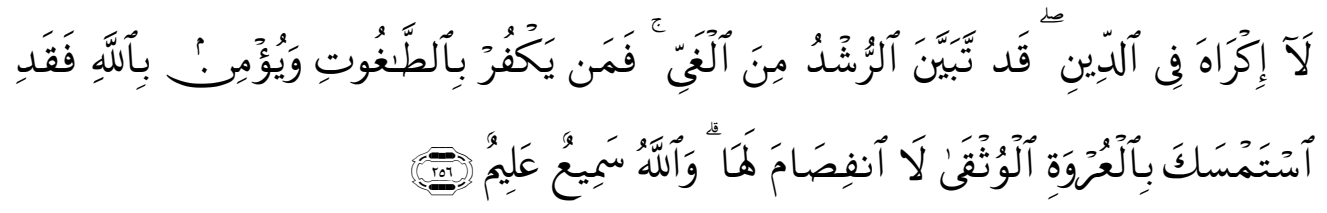

Tidak ada paksaan untuk (memasuki) agama (Islam); sesunggubnya telah jelas jalan yang benar daripada jalan yang sesat. Karena itu barangsiapa yang ingkar kepada Thaghut dan beriman kepada Allah, maka sesunggubnya ia telah berpegang kepada bubul tali yang amat kuat yang tidak akan putus. Dan Allah Maha Mendengar lagi Maha Mengetabui.

Ketiga, Prinsip tolong menolong antara umat muslim dan kaum Yahudi, termaktub pada pasal 11-18. Prinsip ini sesuai dengan sabda Rasulullah yang berbunyi :

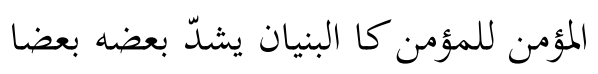


Orang mukmin bagi orang mukmin lain seperti sebuah bangunan sebagiannya memperkokoh sebagian yang lain.

Keempat, Prinsip perdamaian antara muslim dan yahudi pada pasal 45 . Prinsip ini sesuai dengan firman Allah ta'ala surat Al-Hujurat/49:9 yang artinya:

'Dan kalau ada dua golongan dari mereka yang beriman itu berperang hendaklah kamu damaikan antara keduanya! tapi kalau yang satu melanggar Perjanjian terhadap yang lain, hendaklah yang melanggar Perjanjian itu kamu perangi sampai surut kembali pada perintah Allah".

Kelima, Prinsip saling menghormati dalam hidup bertetangga hal ini termaktub pada pasal 40-41 dalam piagam. Dan prinsip ini sesuai dengan firman Allah surat An-Nisa'/4: 36 sebagai berikut,

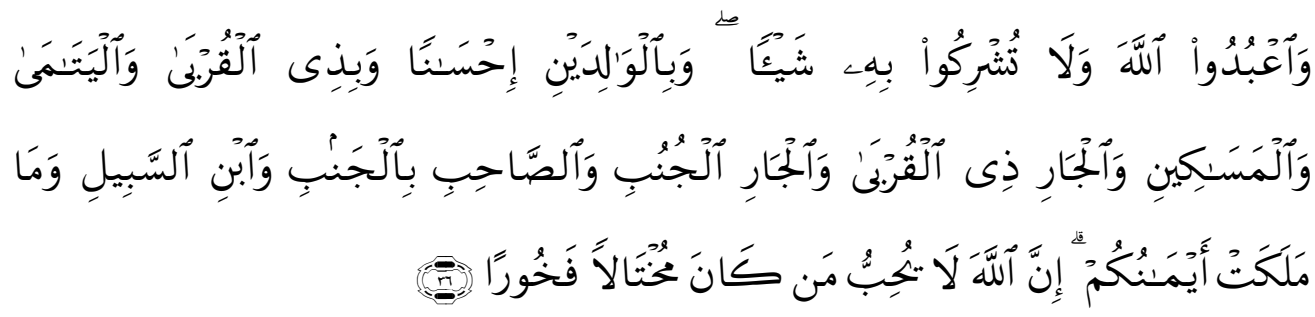

Sembahlah Allah dan janganlah kamu mempersekutukan-Nya dengan sesuatupun. Dan berbuat baiklab kepada dua orang ibu-bapa, karib-kerabat, anak-anak yatim, orang-orang miskin, tetangga yang dekat dan tetangga yang jauh, dan teman sejawat, ibnu sabil dan hamba sahayamu. Sesunggubnya Allah tidak menyukai orang-orang yang sombong dan membangga-banggakan diri.

Prinsip-prinsip di atas merupakan rangkuman yang ada dalam piagam Madinah, secara tidak langsung jika diperhatikan piagam tersebut telah mempraktekkan sistem multikulturalisme, yang pada kenyataannya mampu membawa pada kehidupan yang madani.

\section{d. Hambatan Nabi dalam membumikan Multikultural di Madinah}

Sebelum Nabi SAW Hijrah ke Madinah, ayat-ayat Alquran yang diturunkan Allah di Mekkah lebih banyak membicarakan masalah tauhid yang notabene merupakan pondasi terpenting dalam masalah akidah/kepercayaan. Barulah ketika di Madinah, ayat-ayat yang turun lebih banyak menyangkut hukum-hukum Islam, di mana secara langsung Islam berusaha membangun kaidah-kaidah sosial untuk menciptakan masyarakat yang madani. Termasuk dari ayat-ayat madaniyah adalah ayat-ayat yang merespon berbagai macam kultur dan agama yang ada di Madinah pada waktu itu.

Kultur merupakan sesuatu yang dimiliki oleh sebuah komunitas yang berlaku dan mengikat semua komponen didalamnya, maka multikulturalisme 
adalah jawaban untuk bertemunya antara kultur yang beragam dalam bingkai saling menghargai satu budaya dengan budaya yang berbeda. ${ }^{19}$

Multikulturalisme dapat ditemukan dalam beberapa penjelasan yang tertuang di dalam beberapa ayat Alquran, diantaranya adalah terdapat dalam Q.S. Al-Hujurat ayat 13. Di sana dikatakan, Tuhan menciptakan laki-laki dan perempuan tanpa membeda-membedakan derajatnya. Tuhan juga menjadikan umat manusia bersuku-suku, berbangsa-bangsa, dan berkelompok-kelompok. Semua dipandang sama oleh Tuhan. Tujuannya Cuma satu: "Li ta'arafu" (untuk saling mengenal satu sama lain secara baik. ${ }^{20}$

\section{Multikultural di Makkah}

Nabi Muhammad SAW menerima wahyu yang pertama di Gua Hira di Makkah pada tahun 610 M. Dalam wahyu itu termaktub ayat Alquran yang artinya: "Bacalah (ya Muhammad) dengan nama Tuhanmu yang telah menjadikan (semesta alam). Dia menjadikan manusia dari segumpal darah. Bacalah, dan Tuhanmu maha pemurah. Yang mengajarkan dengan pena. Mengajarkan kepada manusia apa yang belum diketahuinya.

Kemudian disusul oleh wahyu yang kedua termaktub ayat Alquran yang artinya: Hai orang yang berkemul (berselimut). Bangunlah, lalu berilah peringatan! dan Tuhanmu agungkanlah! dan pakaianmu bersihkanlah dan perbuatan dosa tinggalkanlah dan janganlah kamu member (dengan maksud) memperoleh (balasan) yang lebih banyaK dan untuk (memenuhi perintah) Tuhanmu, bersabarlah.

Dengan turunnya wahyu itu Nabi Muhammad SAW telah diberi tugas oleh Allah, supaya bangun melemparkan kain selimut dan menyingsingkan lengan baju untuk memberi peringatan dan pengajaran kepada seluruh umat manusia, sebagai tugas suci, tugas mendidik dan mengajarkan Islam.kemudian kedua wahyu itu diikuti oleh wahyu-wahyu yang lain. Semuanya itu disampaikan dan diajarkan oleh Nabi, mula-mula kepada karib kerabatnya dan teman sejawatnya dengan sembunyi-sembunyi.

Setelah banyak orang memeluk Islam, lalu Nabi menyediakan rumah AlArqam bin Abil Arqam untuk tempat pertemuan sahabat-sahabat dan pengikutpengikutnya. di tempat itulah pendiikan Islam pertama dalam sejarah pendidian Islam.disanalah Nabi mengajarkan dasar-dasar atau pokok-pokok agama Islam kepada sahabat-sahabatnya dan membacakan wahyu-wahyu (ayat-ayat) Alquran

\footnotetext{
${ }^{19}$ Nurul Mubin, Teologi Multikultural: Upaya Membumikan Dimensi Transendental Di tengah Keragaman Suku, Budaya dan Agama, ..., h. 96.

${ }^{20}$ Nurul Mubin, Teologi Multikultural: Upaya Membumikan Dimensi Transendental Di tengah Keragaman Suku, Budaya dan Agama, ..., h. 98.
} 
kepada para pengikutnya serta Nabi menerima tamu dan orang-orang yang hendak memeluk agama Islam atau menanyakan hal-hal yang berhubungan dengan agama Islam. Bahkan disanalah Nabi beribadah (sholat) bersama sahabat-sahabatnya. ${ }^{21}$

Lalu turunlah wahyu untuk menyuruh kepada Nabi, supaya menyiarkan agama Islam kepada seluruh penduduk jazirah Arab dengan terang-terangan. Nabi melaksanakan tugas itu dengan sebaik-baiknya. Banyak tantangan dan penderitaan yang diterima Nabi dan sahabat-sahabatnya. Nabi tetap melakukan penyiaran Islam dan mendidik sahabat-sahabatnya dengan pendidikan Islam.

Dalam masa pembinaan pendidikan agama Islam di Makkah Nabi Muhammad juga mengajarkan Alquran karena Alquran merupakan inti sari dan sumber pokok ajaran Islam. Disamping itu Nabi Muhamad SAW, mengajarkan tauhid kepada umatnya. ${ }^{22}$

Intinya pendidikan dan pengajaran yang diberikan Nabi selama di Makkah ialah pendidikan keagamaan dan akhlak serta menganjurkan kepada manusia, supaya mempergunakan akal pikirannya memperhatikan kejadian manusia, hewan, tumbuh-tumbuhan dan alam semesta seagai anjuran pendidikan 'akliyah dan ilmiyah.

Adapun tahap pendidikan multikultural di Makkah sebagai berikut:

a. Tahap rahasia dan perorangan

Pola pendidikan yang dilakukan adalah secara sembunyi-sembunyi, mengingat kondisi sosiopolitik yang belum stabil, dimulai dari dirinya sendiri dan keluarga dekatnya.

b. Tahap terang-terangan

Pendidikan secara sembunyi-sembunyi berlangsung selama tiga tahun kemudian turun wahyu berikutnya, yang memerintahkn dakwah secara terbuka dan terang-terangan. Perintah dakwah secara terang-terangan dilakukan oleh Rasulullah, seiring dengan jumlah sahabat yang semakin banyak dan untuk meningkatkan jangkauan seruan dakwah, karena diyakini dengan dakwah tersebut, banyak kaum Quraisy yang akan masuk Islam.

c. Tahap untuk Umum

Hasil seruan dakwah secara terang-terangan yang terfokus kepada keluarga dekat, kelihatannya belum maksimal sesuai dengan apa yang diharapkan. Maka, Rasulullah mengubah strategi dakwahnya dari seruan yang terfokus kepada keluarga dekat beralih kepada seruan umum, umat manusia secara keseluruhan.

${ }^{21}$ Mahmud Yunus, Sejarah Pendidikan Islam. Jakarta: PT. Hidakarya Agung, 1992, h. 6.

22 Zuhairini, dkk, Sejarah Pendidikan Islam, Jakarta: Bumi Aksara, cet.9, 2008, h. 28. 


\section{Penutup}

Dari paparan di atas, keanekaragaman budaya adalah sebuah keniscayaan dalam hidup. Kehidupan yang tenang dan damai diantara bermacam perbedaan dalam bermasyarakat perlu disosialisasikan agar benar-benar terwujud.

Pandangan atau tinjauan Alquran tentang multikultural pada dasarnya sudah ada dalam ajaran Islam sejak jaman Rasulullah sampai sekarang. Keanekaragaman yang ada justru menjadi kekayaan intelektual untuk dikaji, sebagaimana beberapa ayat Alquran yang menjelaskan hal tersebut. Dengan pendidikan multikultural diharapkan setiap individu atau kelompok bisa menerima dan menghargai setiap perbedaan, hidup berdampingan dengan damai dan tenang, sehingga terbentuk sebuah negara dan bangsa yang damai dan sejahtera.

Pandangan Alquran tentang multikultural meliputi lima karakter, yaitu belajar hidup dalam perbedaan, membangun tiga aspek mutual (saling percaya, pengertian, dan menghargai), terbuka dalam berfikir, apresiasi dan interdependensi, serta resolusi konflik dan rekonsiliasi nirkekerasan. Dari beberapa karakteristik tersebut, diformulasikan dengan ayat-ayat Alquran dan tafsir sebagai dalil, bahwa konsep pendidikan multikultural ternyata selaras dengan ajaran-ajaran Islam dalam mengatur tatanan hidup manusia di muka bumi ini, terutama sekali dalam konteks pendidikan.

Dengan memahami konsep multikulturalisme diharapkan setiap individu atau kelompok bisa menerima dan menghargai setiap perbedaan, hidup berdampingan dengan damai dan tenang walaupun berbeda-beda. Sehingga terbentuk sebuah negara dan bangsa yang damai dan sejahtera.

\section{Daftar Pustaka}

Abdullah, Pendidikan Multikultural di Pesantren. Yogyakarta: Disertasi pada Pascasarjana UIN Sunan Kalijaga, 2009.

Agustian, Murniati, Pendidikan Multikultural, Jakarta: Unika Atmajaya, 2015.

Ali, Muhamad. Teologi Pluralis Multikultural: Menghargai Kemajemukan Menjalin Kebersamaan.Jakarta: Kompas, 2003, cet. ke-1

Amin, Muhamad Suma Studi Ilmu-ilmu Alquran 3. Jakarta: Pustaka Firdaus, 2004.

Arifin, Muhammad, Filsafat Pendidikan Islam. Jakarta: Bina Aksara, 1987.

Banks, James A., Multikultural Education and Goals,New York: John Wiley \& Sons, 2010.

Baidhawi, Zakiyuddin, Pendidikan Agama Berwawasan Multikultural, Jakarta: Erlangga, 2005. 
Departemen Agama Republik Indonesia, Al Qur'an dan Terjemahnya, Jakarta: CV. Indah Press 1994.

Hamied, Fuad A. dan Syihabuddin, ed. Memelihara Kerukunan Melalui Pendidikan Multikultural.Jakarta: Kedeputian Bidang Koordinasi Pendidikan, Agama, dan Aparatur Negara, 2009.

Hernandez, Hilda, Multicultural Education: A Teacher Guide to Linking Context, Process, and Content. New Jersey: Prentice Hall, 1989

Kymlicka, Will. Kewargaan MultikulturaL Teori Liberalmengenai Hak-bak

Minoriytas, terj. Edlina Hafmini Eddin. Jakarta: LP3ES, 2003.

Latif, Yudi, Menyemai Karakter Bangsa.Jakarta: Kompas, 2009, cet. ke-1.

Ma'mun Ibnu Ridwan, Politik Perkotaan Berbasis Multikultural, (Kajian atas Hubungan Etnis dan Agama di Jakarta), Jakarta: Pustaka Cerdasindo, 2006.

Machali, Imam, Musthofa, Pendidikan Islam dan Tantangan Globalisasi (Buah Pikiran Seputar; Filsafat, Politik, Ekonomi, Sosial dan Budaya), Jogjakarta: Ar-Ruzz Media, 2004.

Mahfud, Choirul, Pendidikan Multikultural, Yogyakarta: Pustaka Pelajar, 2006.

Maslikhah, Quo Vadis Pendidikan Multikultur, Surabaya: STAIN Salatatiga Press dan JP Books, 2007.

Muhaimin dan Abd. Mujib, Pemikiran Pendidikan Islam. Bandung: Trigenda Karya, 1993.

Nurul Mubin, Teologi Multikultural: Upaya Membumikan Dimensi Transendental Di tengah Keragaman Suku, Budaya dan Agama, Jurnal Manarul Qur'an, Nomor: 09 tahun VII, Januarai-Maret 2001.

Parekh, Bhikhu, terj. C.B. Bambang Kukuh Adi, Rethinking Multikultirism: Keberagaman Budaya dan Teori Politik, Cet. Ke-5 Yogyakarta: Kanisius, 2008.

Pulungan, Suyuthi, Prinsip-Prinsip Pemerintahan dalam Piagam Madinah Ditinjan Dari Pandangan Alquran, Jakarta: PT. Raja Grafindo, Cet. Ke-1, 199

Rahman, Fazlur, Islam and Modernity, Transformation of an Intellectual Tradition, Chicago: The University of Chicago Press, 1982.

Shihab, M. Quraish, Tafsir al-Mishbah: Pesan, Kesan, dan Keserasian alQur'an, Volume 1, Jakarta : Lentera, 2000.

Sumartana, dkk., Pluralisme, Konflik, dan Pendidikan Agama di Indonesia, Yogyakarta: Interfidei dan Pustaka Pelajar, 2001.

Suparta, Mundzier, Islamic Multicultural Education: Sebuah Refleksi atas Pendidikan Agama Islam di Indonesia, Jakarta: Al-Ghazali Center, 2008 
204 | AL QUDS : Jurnal Studi Al Quran dan Hadis vol. 1, no 2, 2017

"Membangun Integrasi Ilmu dan Agama: Pengalaman UIN Malang" dalam Zainal Abidin Bagir dkk. [Ed.], Integrasi Ilmu dan Agama: Interpretasi dan Aksi, Bandung: Mizan, 2005.

Sutarno, Pendidikan Multikultural. Jakarta: Ditjen Dikti, 2007.

Suriasumantri, Jujun S., Filsafat Ilmu: Sebuah Pengantar, Jakarta: Sinar Harapan, 1984.

Suyudi, Muhammad, Pendidikan Perspektif Alquran. Yogyakarta: Mikraj, 2005.

Sumartana, dkk., Pluralisme, Konflik, dan Pendidikan Agama di Indonesia, Yogyakarta: Interfidei dan Pustaka Pelajar, 2001.

Suryana, Yaya dan H. A.Rusdiana, Pendidikan Multikultural (Suatu Upaya Penguatan Jati Diri Bangsa) Bandung: Pustaka Setia, 2015.

Stavenhagen, Rudolfo., Education for Multikultural World dalam Jasque Delors (et.all.). Learning: the Treasure Within. Paris: UNESCO, 1996.

Sleeter, C.E., Making Choice for Multikultural Education: Five Appoaches to Race, Class and Gender. New York: John Wiley \& Sons, 1999.

L.Tiedt, Pamela dan Iris M. Tiedt, Multicultural Teaclling: $A$ Handbook of Activities Information and Research, USA: Pearson Education Inc, 2005

UU RI Nomor 20 Tahun 2003 tentang Sistem Pendidikan Nasional. Jakarta: Cemerlang, 2003

Wahid, Abdurrahman, Islamku Islam Anda Islam Kita, Jakarta: The Wahid Institute, 2006

Yunus, Mahmud, Sejarah Pendidikan Islam. Jakarta: Hidarya Agung, 1981.

Yaqin, Ainul, Pendidikan Multikultural (Cross Cultural Understanding Untuk Demokrasi dan Keadilan, Yogyakarta:Kanisius, 2000.

Zaenudin dkk, Seluk Beluk Pendidikan dari al-Ghazali. Jakarta: Bumi Aksara, 1992.

Zamroni, The Implementation of Multikultural Education. A Reader. Yogyakarta: Graduate Program The State University of Yogyakarta, 2010. A Conception Frame-Work of Multikultural Teschers Education. A reader. Yogyakarta: Graduate Program The State University of Yogjakarta, 2010. Pendidikan Demokrasi pada Masyarakat Multikultural. Yogyakarta: Gavin Kalam Utama, 2011 